\title{
METODE DAKWAH DALAM MEMBINA KELUARGA SAKINAH (Studi Pada Kelompok Pengajian di Kecamatan Jati Agung Kabupaten Lampung Selatan)
}

\author{
M. Nasor \\ Efa Rodiah Nur \\ Dosen Fakultas Dakwah dan Syariah UIN Raden Intan Lampung \\ J1. Endro Suratmin Sukarame Bandar Lampung \\ Email: nasor@,radenintan.ac.id \\ efarodiahnur@,radenintan.ac.id
}

\begin{abstract}
Abstrak : Hakekat dakwah pada dasarnya adalah upaya mengajak dan mengembalikan manusia pada fitrah dan kehanifannya. Untuk itu kegiatan dakwah menitik beratkan materinya pada pemurnian aqidah, masalah nilai-nilai sosial, keadilan, kesejahteraan, kebersamaan, kebebasan, dan lain sebagainya. Materi dakwah dalam pembinaan masyarakat yaitu memberantas segala bentuk kemusyrikan dan takhayul juga materi yang berhubungan dengan kemaslahatan hidup bermasyarakat.

Kegiatan dakwah yang dilaksanakan oleh pengurus pengajian menggunakan berbagai metode dengan tujuan untuk memperoleh hasil yang diinginkan. Dalam penelitian ini dapat dirumuskan permasalahannya sebagai berikut: "Bagaimana metode dakwah dalam membina Keluarga Sakinah pada kelompok Pengajian di Kecamatan Jati Agung Lampung Selatan?.

Penelitian ini mengambil jenis penelitian lapangan (field research) yaitu jenis penelitian yang dilakukan di suatu tempat yaitu penelitian yang dilakukan dalam kehidupan sebenarnya. Mengenai sumber data dalam penelitian ini adalah pendapat para jamaah yang mengikuti pengajian yang diadakan oleh kelompok pengajian dan para pengurus pengajian.

Hasil penelitian beberapa metode dakwah yang telah digunakan oleh pengurus pengajian dalam membina masyarakat untuk mewujudkan keluarga sakinah, yaitu: metode dakwah bil-hikmah, metode dakwah mau'idzah hasanah, metode dakwah mujadalah, metode dakwah bil-lisan atau ceramah, metode dakwah tanya jawab, mtode dakwah bil hal, dan metode dakwah keteladanan.
\end{abstract}

Kata kunci: Metode Dakwah, Keluarga Sakinah, Kelompok Pengajian

\section{A. Pendahuluan.}

Hakekat dakwah pada dasarnya adalah upaya mengajak dan mengembalikan manusia pada fitrah dan kehanifannya. Untuk itu kegiatan dakwah menitik beratkan materinya pada pemurnian aqidah, masalah nilainilai sosial, keadilan, kesejahteraan, kebersamaan, kebebasan, dan lain sebagainya. Materi dakwah dalam pembinaan aqidah yaitu memberantas segala bentuk kemusyrikan dan takhayul diganti diarahkan yang berhubungan masyarakat untuk mengenal Tuhan yang sebenarnya yaitu Allah SWT. Kegiatan dakwah dalam pemurnian aqidah akan mewujudkan keimanan/keyakinan masyarakat menjadi kuat sebagaimana disinyalir oleh Muhammad Hasiem bahwa pemurnian aqidah melalui kegiatan keagamaan akan mewujudkan keyakinan masyarakat menjadi kuat dan terhindar dari penyembahan- 
penyembahan yang menyesatkan dan juga akan terhindar dari penghambaan terhadap thaghut. ${ }^{1}$ Materi dakwah selain pemurnian aqidah juga pembinaan dan pengembangan sistem sosial secara menyeluruh. Pembinaan kemasyarakatan semacam itu bertujuan untuk membangun sebuah tatanan masyarakat yang berperadaban atau masyarakat yang memiliki tatanan sosial kehidupan yang lebih maju. Asghar Ali menjelaskan bahwa Nabi SAW sangat peduli dalam masalah menghilangkan perbedaan atau kesenjangan sosial dan tentang perekonomian. ${ }^{2}$

Kegiatan dakwah dengan pemurnian aqidah bukan saja sekedar memiliki prinsip dasar keimanan yang kuat tetapi juga dapat mewujudkan prinsip dasar moral dan etika sosial. Dalam kondisi semacam ini dasar keimanan yang kuat akan dapat mewujudkan kehidupan yang selaras dengan kehidupan seharihari seperti rasa keadilan sosial, keamanan, saling tolong menolong, menghormati, dan lainnya. Melalui peresiapan yang mendalam terhadap ke-Maha Esa-an Tuhan ( tauhid) ini akan melahirkan kehidupan yang penuh moral, yang akan termanifestasi bukan saja dalam aspek sosio-ekonomi, tetapi juga aspek sosio-politiknya dengan sikap penegakan keadilan di antara sesama manusia. ${ }^{3}$ Pemurnian aqidah yang ditanamkan melalui kegiatan dakwah selain untuk menguatkan keimanan agar tidak terpengaruh

1 Muhammad Haseim al-Mahasibi, Tafsir Wa Bayan Ma'a Sabab al-Nuzul li alSuyuthi, Beirut: Dar al-Rasyid, t., th., hal. 42.

${ }^{2}$ Asghar Ali Inginer, Asal Usul dan Perkembangan Islam Analis Perkembangan Ekonomi, terj. Imam Baihaqi, Yogyakarta: Pustaka Pelajar, 1999, hal. 68.

${ }^{3}$ Nurcholish Madjid, Keislaman, Keindonesiaan dan Kemodernan,Bandung: Mizan, 1992, hal. 51. keyakinan lain, juga akan dijadikan landasan bagi umat Islam untuk membangun jalinan sosial dalam kehidupan bermasyarakat. Prinsip semacam ini yaitu sikap hidup dan perilaku seorang muslim yang memilik kepercayaan (aqidah tauhid) yang baku dan tidak boleh ada intervensi dari pihak lain, namun juga memiliki dan melakukan nilai-nilai keutaman sosial untuk menjalin hubungan dalam kehidupan manusia. Metode dakwah dalam pembinaan masyarakat merupakan pembinaan kelompok ummat Islam sebagai upaya melaksanakan amar ma'ruf nahi munkar. Aktivitas dakwah yang mendasarkan al-Qur'an dan al-Hadits memberikan pedoman untuk menumbuhkan-kembangkan

kehidupan beragama, kehidupan sosial, dan penguasaan serta pengelolaan alam semesta. Nilai-nilai tersebut harus diajadikan landasan kuat untuk dijadikan arahan dalam mewujudkan kehidupan masyarakat yang berperadaban baik, dengan mengacu pada prinsip yaitu: (1) peradaban Islam berdiri atas landasan tauhid, (2) peradaban yang bersifat manusiawi, bersifat transendental, dan memiliki wawasan internasional, (3) selalu memegang prinsip moral, (4) percaya pada ilmu pengetahuan yang benar, dan (5) memiliki toleransi dalam beragama. ${ }^{4}$

Metode dakwah merupakan sesuatu unsur kegiatan yang terpenting dalam kehidupan manusia, kapanpun, di manapun berada yang selalu membutuhkan dakwah. Melalui metode komunikasi dakwah akan dapat mencapai tujuan dan menghasilkan apa yang diinginkannya. Di samping itu juga melalui metode isi pesan dakwah

${ }^{4}$ Mustofa al-Siba'i, Rawai Hadaratina, Beirut: Dar al-Irsyad, 1968, hal. 29. 
akan lebih mudah diterima, mudah dimahami orang lain, gagasan yang disampaikan dengan persuasif, dan mudah menggerakkan orang lain.

Metode dakwah seyogyanya mengacu pada ketentuan yang diamanatkan oleh al-Qur'an yang termuat dalam surat An-Nahl ayat 125 yang berbunyi sebagai berikut:

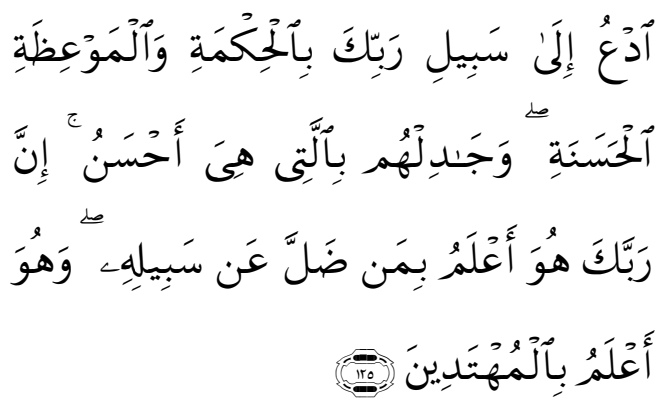

Serulah (manusia) kepada jalan Tuhanmu dengan hikmah dan pelajaran yang baik dan bantahlah mereka dengan cara yang baik. Sesungguhnya Tuhanmu Dialah yang lebih mengetahui tentang siapa yang tersesat dari jalan-Nya dan Dialah yang lebih mengetahui orangorang yang mendapat petunjuk. ${ }^{5}$

Ayat di atas memberikan petunjuk mengenai penggunaan metode dakwah yaitu dengan hikmah, pelajaran yang baik, dan mujalah. Dari metode itu harus dimanfaatkan dan disinergikan agar pembinaan keluarga sakinah melalui kegiatan dakwah memperoleh efektivitas tersendiri. Begitu pula hubungannya dengan membina keluarga sakinah diperlukan suatu metode dakwah dapat terjalin komunikasi efektif dan memiliki makna yang mampu mengarahkan orang tua dan anggota keluarganya dalam pencapaian tujuan pembinaan keluarga sakinah.

Dalam Islam keluarga seyogyanya terjadi jalinan komunikasi yang baik,

${ }^{5}$ Depag. RI, Al-Qur'an dan Terjemahnya, Jakarta, Yayasan Penterjemah/Penafsir alQur'an, 1971, hal. 421. agar umpan balik yang diberikan anak kepada orang tua juga baik. Orang tua muslim tidak hanya memberikan informasi semata, tetapi hendaknya mengarahkan anggota keluarganya menguasai berbagai kajian ke Islaman serta dapat mengamalkannya dalam kehidupan sehari-hari. Kondisi ini akan dapat menata dan membentuk perkembangan jiwa dengan baik, sehingga akan memiliki sikap dan perilaku religious yang baik.

Kegiatan dakwah seyogyanya memberikan penanaman nilai-nilai akhlak yang baik kepada anggota keluaga, hal itu mutlak diperlukan untuk mencapai keharmonisan dalam menjalani kehidupan. Nilai-nilai tersebut dijadikan dasar kehidupan agar mereka tidak menyimpang dari aturanaturan ajaran Islam. Upaya ini di lingkungan keluarga sangat membantu agar memiliki kepribadian atau tingkah laku yang baik. Pada prinsipnya anggota keluarga wajib membekali dirinya tentang nilai-nilai akhlak agar memiliki pengetahuan dan mampu mengaplikasikannya dalam kehidupan sehari-hari.

Dengan demikian keluarga dapat melaksanakan ritual-ritual keagamaan atau ibadah yang sesuai dengan ajaran Islam dan memiliki akhlak mulia atau berbudi luhur. Untuk menyikapi hal tersebut dapat ditelaah kegiatan dakwah yang dilakukan oleh Kelompok Jama'ah Pengajian Miftahul Jannah di Kelurahan Way Huwi Jati Agung Lampung Selatan yang telah lama melakukan pembinaan keluarga sakinah. Dari hasil prasurvey diperoleh gambaran ternyata sebahagiaan besar kondisi sikap dan perilaku anggota masyarakat memperlihatkan adanya budi pekerti yang baik. Kemudian hasil wawancara dengan masyarakat bahwa proses pembinaan akhlak/kepribadian 
baik atau keluarga sakinah diperoleh dari ikut kegiatan pengajian. Kenyataan ini diperoleh berkat adanya kegiatan dakwah/pengajian Kelompok Jama'ah Pengajian di Kecamatan Jati Agung Kabupaten Lampung Selatan telah banyak memberi pengarahan mengenai materi keluarga sakinah. Hasil pembinaan tersebut telah dapat membentuk prilaku masyarakat yang memiliki akhlak yang baik.

Tercerminlah akhlak itu yaitu terlihat adanya beberapa sikap dan perilaku seperti: memahami tanggung jawab/hak suami istri, faham mengenai kewajiban orang tua, saling menghormat, tolong menolong, saling menghargai, bekerjasama, dan lainnya.

Menurut kenyataannya masyarakat memahami masalah keluarga sakinah secara umum berasal dari mengikuti pengajian rutin yang dilakukan oleh Kelompok Jama'ah Pengajian yang diselenggarakan oleh pengurus pengajian tersebut. Kelompok pengajian ini beridiri sejak bertahuntahun lamanya kurang lebih 20 tahunan dan memang telah memiliki kiprah/kegiatan bidang keagamaan dan bidang sosial. Jama'ah pengajian ini di Kecamatan Jati Agung dapat dijadikan parameter dalam keagamaan amar ma'ruf nahi munkar termasuk permasalahan keluarga sakinah.

Kegiatan pengajian tersebut memiliki berbagai kegiatan dalam mencapai sasarannya, yakni dilakukannya pelbagai kegiatan keagamaan dengan penceramah lokal dan penceramah dari luar daerah. Selain kegiatan keagamaan juga dilakukan kegiatan sosial seperti mengunjungi orang sakit dan menyantuni yang kurang mampu serta bakti sosial, juga disediakan ruang tanya jawab dan konsultasi.
Masyarakat memahami bahwa melalui Kelompok Jama'ah Pengajian Kecamatan Jati Agung dirasakan banyak manfaatnya dalam menghimpun potensi masyarakat khususnya dalam membina keluarga sakinah. Dalam pelbagai kegiatan pengajian yang diselenggarakan oleh Kelompok Jama'ah Pengajian itu masyarakat dapat merealisasikan hidup berkeluarga secara Islami. Anjuran yang ditujukan pada jama'ah itu terutama untuk memahami dan melaksanakan kewajiban/hak selaku suami, istri, dan anak sesuai aturan Islam yang akan mendatangkan kebahagiaan. Materimateri pengajian yang hubungannya untuk membina keluarga sakinah seputar masalah perkawinan menurut ajaran Islam, kewajiban kepala keluarga menurut ajaran Islam, perkawinan yang sekufu, perkawinan batasan muda sesuai/menurut ajaran Islam, dan materi-materi kewajiban/hak anak-anak dalam keluarga.

Kegiatan dakwah yang dilakukan oleh Kelompok Jama'ah Pengajian dalam membina keluarga sakinah mendapat respons baik dari masyarakat, karena memiliki kontribusi positif terhadap kehidupan mereka.

Dalam kegiatan pengajian itu menghadirkan da'i dari luar dan juga da'i dari kalangan sendiri. Para jamaah sangat antusias dalam kegiatan itu dan menganggap cukup membantu jama'ah dalam memperluas cakrawala pemikiran tentang keluarga sakinah.

Metode dakwah yang dilakukan oleh para da'i sangat variatif disesuaikan dengan kondisi para pendengarnya. Perhatian jama'ah sangat besar sehingga jama'ah merasakan kemanfaatannya terutama dalam mengatur anggota keluarganya untuk mencapai kehidupan yang harmonis. 
Melalui metode tersebut para da'i memanfaatkan waktu kurang lebih 2 (dua) jam, namun kegiatan itu mampu menumbuhkan aspirasi para jamaah dalam memahami hak dan kewajiban masing-masing anggota keluarga untuk hidup rukun, saling menghormati, dan damai. Seiring dengan berjalannya waktu pengajian itu mampu mengenalkan norma-norma sosial, menumbuhkan selera, sebagai alat pendidik, mampu merubah sikap, dan merubah perilaku. Bahkan lebih dari itu anggota jama'ah pengajian mampu menciptakan suasana membangun empati, persatuan kesatuan, dan hidup kebersamaan antar keluarga serta masyarakat.

Melalui berbagai identifikasi metode kegiatan pengajian di Jati Agung Lampung Selatan di atas, dapat diambil rumusan permasalahannya adalah: "Bagaimana penerapan metode dakwah dalam membina Keluarga Sakinah pada kelompok Pengajian Jama'ah di Kecamatan Jati Agung Lampung Selatan?.

\section{B. Metode Penelitian}

Penelitian ini mengambil jenis penelitian lapangan (field research) yaitu jenis penelitian yang dilakukan di suatu tempat yaitu penelitian yang dilakukan dalam kehidupan sebenarnya. ${ }^{6}$ Selain jenis di atas juga menggunakan jenis penelitian kualitatif pendapat Maman Rahman bahwa penggunaan metode penelitian kualitatif mengarahkan pada pusat perhatian kepada cara bagaimana memberi makna pada kehidupannya.

Pada pengertian lain peneliti menekankan pada titik pandang orangorang atau yang disebut people's point of view dan pemaparan hasil penelitian berdasarkan data dan informasi

6Kartini Kartono, 1996, Pengantar Metodologi Riset Sosial, Bandung: Mandar Maju, hal. 10. lapangan dengan menarik makna dan konsepnya.

S. Margono menjelaskan bahwa jenis penelitian kualitatif adalah prosedur penelitian yang menghasilkan data diskreptif berupa kata-kata tertulis atau lisan dari orang-orang dan perilaku yang diamati. ${ }^{8}$ Data berupa kata-kata atau lisan tidak akan mungkin data pada situasi sosial tersebut dijaring dengan metode kuantitatif. Selanjutnya pula peneliti bermaksud memahami situasi sosial secara mendalam, menemukan pola, hepotesis, dan teori. ${ }^{9}$

Dalam pendekatan penelitiannya penulis melakukan hal-hal yang berhubungan dengan masalah yang sedang diteliti agar dapat menganalisis mengenai kegiatan dakwah dalam membina keluarga sakinah, studi pada kegiatan kelompok pengajian di Kecamatan Jati Agung Kabupaten Lampung Selatan.

Dalam penelitian ini juga diuraikan sifat penelitiannya bersifat deskriptif adalah menggambarkan secara tepat sifat-sifat suatu individu, keadaan, gejala-gejala kelompok tertentu untuk menetapkan adanya hubungan tertentu sesuai gejala di suatu daerah lain di masyarakat. ${ }^{10}$

Penelitian diskreptif yaitu jenis penelitian yang menggambarkan kondisi senyatanya berdasarkan data yang ada di lapangan. Jenis penelitian ini merupakan penelitian yang

7 Maman Rahman, Strategi dan LangkahLangkah Penelitian Pendidikan, IKIP Press, Semarang, 1993, hal. 114.

${ }^{8}$ S. Margono, Metode Penelitian Pendididkan, Penerbit Rinieka Cipta, Jakarta, 2004, hal. 36.

9Sugiyono, Metode Penelitian Administrasi, Penerbit CV. Alfabeta, Bandung 2007, hal. 399.

${ }^{10}$ Koentjoroningrat, 1985, Metode Penelitian Masyarakat, Jakarta: Gramedia, hal. 32. 
bertujuan untuk mengetahui dan menganalisis suatu permasalahan yang ada pada variabel penelitian. Dengan demikian maka akan dapat dibangun teori-teori yang berfungsi untuk menjelaskan, meramalkan, dan mengontrol suatu gejala. ${ }^{11} \mathrm{Hal}$ ini penulis meneliti dan mengkaji informasi dan data yang terkait dengan peran dan fungsi dakwah, serta data yang terkait dengan pesan-pesan dakwah yang diterima oleh masyarakat yang berhubungan dengan pembinaan keluarga sakinah.

Jenis dan penelitian sumber data yang digunakan dalam penelitian ini memakai obyek yang sesuai dengan subyek penelitian yang berhubungan dengan kegiatan pengajian yang dilakukan oleh kelompok pengajian dalam membina keluarga sakinah. Mengenai sumber data dalam penelitian ini adalah pendapat para jamaah yang mengikuti pengajian yang diadakan oleh kelompok pengaiian dan para pengurus pengajian. Diperlukan juga sumber data dari unsur pejabat kelurahan dan tokoh masyarakat serta tokoh agama di Kecamatan Jati Agung Lampung Selatan.

Sumber data dalam penelitian ini dibagi menjadi dua jenis sumber data yaitu sumber data primer/utama (primary sources) dan sumber data sekunder (secondary sources).

1. Sumber data primer/utama (primary sources) adalah data yang diperoleh langsung dari sumber data pertama di lokasi penelitian atau obyek penelitian. Dalam hal ini peneliti memperoleh data langsung dari pengurus pengajian, da'i, dan para jamaah pengajian An-Nisaa' Kecamatan Jati Agung Kabupaten Lampung Selatan.

${ }^{11}$ Sugiyono, Op. Cit., hal. 11.
2. Sumber data sekunder (secondary sources) yaitu data yang diperoleh dari sumber data yang kedua dari data yang dibutuhkan dalam melengkapi hasil penelitian. ${ }^{12}$ Dalam hal ini peneliti mengambil data dari buku-buku, jurnal, artikel, pejabat kelurahan, tokoh agama, dan tokoh masyarakat serta dokumentasi di Kecamatan Jati Agung Lampung Selatan yang berhubungan dengan penelitian ini.

Dalam penelitian ini populasinya adalah segenap pengurus pengajian dan seluruh jamaah pengajian di wilayah Kecamatan Jati Agung Kabupaten Lampung Selatan. Sedangkan sample merupakan bagian atau wakil dari keseluruhan jumlah populasi yang ada atau wakil yang dipilih dari jumlah anggota yang ada. Kesempatan ini peneliti akan menentukan jumlah sample dari populasi yang ada dengan menggunakan teknik non-random sampling, yaitu dalam sampling ini tidak semua individu dalam populasi diberi peluang yang sama untuk dijadikan sample. ${ }^{13}$

Adapun sample yang digunakan untuk mengambil data yang diperoleh melalui sumber data primer dipilih dengan purposive snowball sampling. Purposive sampling adalah teknik pengambilan sumber data dengan pertimbangan tertentu, seperti orang tersebut dianggap paling tahu tentang segala sesuatu yang peneliti harapkan. ${ }^{14}$

Adapun pemahaman mengenai snowball sampling adalah teknik pengambilan sample yang awalnya jumlahnya sedikit, lama-lama menjadi

\footnotetext{
${ }^{12}$ Moh. Nazir, 2005, Metode Penelitian, Bogor: Ghalia Indonesia, hal. 23.

${ }^{13}$ Sutrisno Hadi, 2004, Metode Research, Yogyakarta: Andi Publisher, hal. 80. ${ }^{14}$ Sugiyono, Op. Cit., hal. 300.
} 
besar. ${ }^{15}$ Data yang diperoleh melalui teknik snowball sampling dikarenakan dianggap lebih representatif, baik ditinjau dari pengumpulan data maupun dalam pengembangan data.

Dikatakan representatif bahwa penelitian ini bersifat kualitatif bertolak dari asumsi tentang realitas sosial yang bersifat unik, kompleks dan ganda. ${ }^{16}$

Untuk menentukan samplenya dengan menggunakan metode purposive snowball sampling. Melalui ini peneliti akan memperoleh orang-orang sebagai sumber data dianggap lebih menguasai dan berwenang dalam persoalanpersoalan yang dibutuhkan oleh peneliti.

Adapun kreteria atau sifat-sifat atau ciri-ciri untuk menjadi sample bagi anggota atau jamaah pengajian antara lain:

a. Aktif mengikuti pengajian kurang lebih 3 tahun.

b. Memiliki riwayat pendidikan minimal SLTA.

c. Bisa berkomunikasi baik dengan anggota jamaah lainnya.

d. Berusia antara 25 - 65 tahun.

e. Memiliki keluarga yaitu hidup suami, istri, dan anak dalam keluarga.

Kemudian yang menjadi kreteriasifat untuk menjadi sample yang dikenakan pada pengurus pengajian yaitu:

a. Aktif mengadakan berbagai pembinaan pada masyarakat.

b. Memiliki riwayat pendidikan minimal SLTA.

c. Bisa berkomunikasi baik dengan anggota jamaah lainnya.

d. Berusia antara 25 - 65 tahun.

${ }^{15}$ Ibid.

${ }^{16}$ Muhtar, Bimbingan Skripsi, Tesis, dan Artikel Ilmiah: Panduan Berbasis Penelitian Kualitataif Lapangan dan Kepustakaan, Gaung Persada Press, Ciputat, Jakarta, 2007, hal. 81.
Kreteria-sifat yang dikenakan pada da'i antara lain:

a. Aktif berceramah dalam pembinaan masyarakat.

b. Memiliki riwayat pendidikan minimal S 1.

c. Berusia antara $25-65$ tahun.

Demikianlah beberapa kreteria yang dijadikan pedoman untuk menentukan sumber data dalam penelitian ini. Sumber data yang ditentukan tersebut diharapkan dapat menjaring orangorang yang dianggap mengetahui tentang kegiatan dakwah/pengajian dalam pembinaan keluarga sakinah di Kecamatan Jati Agung Kabupaten Lampung Selatan.

Untuk memudahkan dalam pengambilan data yang ada di lapangan peneliti menggunakan beberapa alat pengumpul data. Alat pengumpulan data pada penelitian ini melalui teknik interviu, observasi, dan dokumentasi.

Data yang harus dikumpulkan melalui tehnik interviu ini adalah data tentang tanggapan dan opini pengurus pengajian, individu jama'ah, pejabat setempat, dan tokoh agama yang berhubungan pelaksanaan pengajian dalam membina keluarga sakinah di Kecamatan Jati Agung Lampung Selatan.

Observasi suatu teknik memperoleh gambaran data melalui pengamatan mengenai pelaksanaan pengajian yang berhubungan dengan pembinaan keluarga sakinah di Kecamatan Jati Agung Lampung Selatan. Observasi yang digunakan untuk memperoleh data yang sesuai dengan permasalahan adalah jenis observasi langsung, yaitu melakukan pengamatan secara langsung dan aktif mengikuti pelaksanaan berbagai pengajian yang kaitannya dengan pembinaan keluarga sakinah.

Tehnik pengumpulan data melalui dokumentasi ini dimaksudkan untuk 
mendapatkan data mengenai, gambaran umum Kecamatan Jati Agung yang meliputi letak geografis, struktur organisasi pemerintahan keluarahan, keadaan ummat beragama, keadaan perekonomian, kondisi kebudayaan, keadaan lembaga sosial, dan keadaan lembaga pendidikan, serta keadaan lembaga pengajian.

Setelah data terkumpul dengan baik, baik yang didapat dari lapangan maupun dari kepustakaan proses selanjutnya diadakan analisa data sesuai dengan permasalahan dalam penelitian ini.

Berikutnya dilakukan pengambilan kesimpulann dengan cara/bersifat induktif adalah penganalisaan dengan cara menarik kesimpulan atas data yang berhasil dikumpulkan dari yang berbentuk khusus kepada bentuk umum. Data yang diteliti dalam penelitian ini adalah data yang berhubungan dengan kegiatan dakwah kelompok pengajian yang berhubungan dengan pembinaan keluarga sakinah di Kecamatan Jati Agung Lampung Selatan.

\section{Hasil Penelitian dan Pembahasan.}

1. Metode Dakwah Kelompok Pengajian dalam membina Keluarga Sakinah

Metode dalam kegiatan dakwah kedudukannya sangat penting untuk meraih keberhasilan. Metode dakwah merupakan suatu jalan yang ditempuh oleh da'i dalam menyampaikan materi dakwah kepada mad'unya agar tujuan dakwah dapat dicapai sebaik mungkin.

Dengan demikian, kita dapat artikan bahwa metode adalah cara atau jalan yang harus dilalui untuk mencapai suatu tujuan. Tujuan dakwah yang hendak dicapai sesuai dengan isyarat alQur'an yaitu mengajak umat manusia baik orang Islam maupun orang-orang non Islam kepada jalan yang benar yang diridhai Allah SWT. Dalam hal ini para da’i dalam dakwahnya telah memiliki metode atau cara -cara tertentu dalam menyampaikan materi dakwah yang ditujukan pada mad'unya. Hal itu bertujuan agar sasaran dakwah dapat menerima materi yang disampaikan secara baik dan nantinya dapat merubah kehidupan keagamaan jama'ah sehingga dapat mengikuti ajaran Islam yang sesungguhnya yaitu berdasarkan al-Qur'an dan sunnah Rasul SAW. ${ }^{17}$

Keadaan sosial-keagamaan para jamaah mayoritas religiusitas masyarakat sudah memiliki tarap pengetahuan agama Islamnya dapat dikatakan relatif baik, termasuk pengetahuan mengenai keluarga sakinah. Hal ini diperoleh dari berbagai kegiatan pengajian yang diselenggarakan oleh kelompok pengajian di berbagai tempat. Melalui kegiatan pengajian tersebut mereka ditempa oleh berbagai materi dakwah yang disampaikan oleh para da'i.

Kebanyakan mereka telah mampu memahami ajaran Islam sebagai suatu kesatuan yang utuh serta mampu merealisasikannya dalam kehidupan sehari-hari. Sadar akan realitas tersebut, maka para da'i terus menerus memberikan pembinaan kepada masyarakat mengenai ajaran Islam, terutama yang berhubungan mengenai keluarga sakinah. Usaha tersebut dicapai melalui pemberian pengetahuan dan pemahaman ajaran agama Islam melalui kegiatan jamaah pengajian.

Dengan adanya kegiatan tersebut lambat laun tingkat keagamaan jama'ah semakin meningkat ke arah yang lebih baik. Selanjutnya kesadaran masyarakat

${ }^{17}$ Hasil Wawancara, Bpk. KH. Ahmad Habib, Penceramah pada kegiatan pengajian Majelis Taklim Jati Agung, Kecamatan Jati Agung Lampung Selatan, tanggal 20 Agustus 2018. 
sedikit demi sedikit minatnya semakin baik berubah ke arah yang lebih baik, terutama yang berkaitan dengan pengetahuan tentang keluarga sakinah.

Dengan berdirinya kelompok pengajian memiliki tujuan untuk mendidik, membina, dan mengembangkan kondisi masyarakat sekitar khususnya untuk mewujudkan keluarga sakinah. Keluarga sakinah kondisi keluarga yang tentram dan bahagia serta saling menghormat di antara anggota keluarga, menuju ke arah keadaan keluarga yang lebih baik sesuai dengan nilai luhur dan ajaran Islam. Perubahan yang diharapkan meliputi tingkat pengetahuan, keberagamaan, dan sosial masyarakat. Faktor yang berperan penting dalam kehidupan beragama di desa-desa wilayah Kecamatan Jati Agung Lampung Selatan. Faktor tersebut adalah keberadaan jama'ah ta'lim dan kelompok pengajian dan terdapat agenda rutin mingguan seperti pengajian bersama dan kegiatan Yasinan. $^{18}$

Kegiatan pengajian yang dilakukan bukan sekedar dilaksanakan tanpa adanya penggunaan metode dan strategi. Agar kegiatan tersebut memperoleh hasil yang diinginkan telah dipersiapkan metode yang baik agar proses dakwah/pengajian berjalan sesuai yang dikehendaki. Penggunaan metode dakwah pada kegiatan pengajian mendasarkan pada alQura'an Surat An-Nahl ayat 125 yang berbunyi sebagai berikut:

${ }^{18}$ Hasil Wawancara, Ibu Sriyani, Kordinator pengajian Ibu-Ibu Kelurahan pada Majelis Taklim Jati Agung, Kecamatan Jati Agung Lampung Selatan, tanggal 25 Agustus 2018.

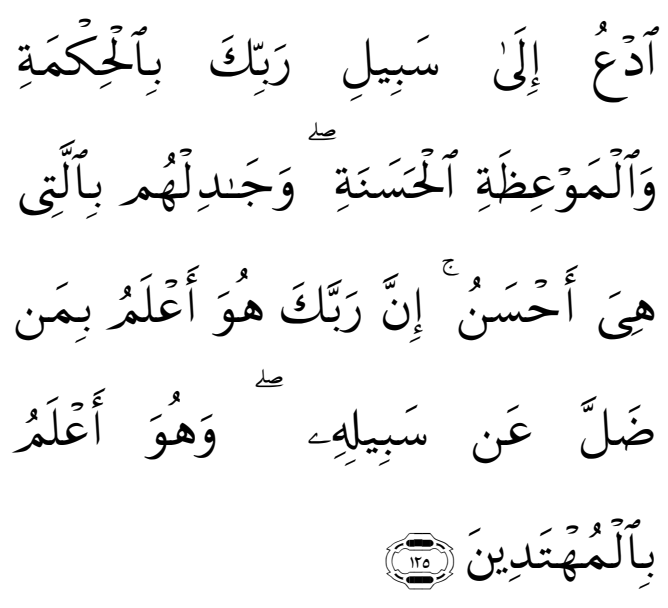

Serulah (manusia) kepada jalan Tuhanmu dengan hikmah dan pelajaran yang baik dan bantahlah mereka dengan cara yang baik. Sesungguhnya Tuhanmu Dialah yang lebih mengetahui tentang siapa yang tersesat dari jalan-Nya dan Dialah yang lebih mengetahui orangorang yang mendapat petunjuk. ${ }^{19}$

Mencermati makna ayat di atas dapat dipahami ada tiga metode yang dapat digunakan dalam melakukan dakwah yaitu bil-hikmah, mau'idzah, dan mujadalah. Nampaknya ketiga metode tersebut telah banyak dipraktekkan oleh seluruh da'i termasuk da'i pada kelompok pengaijan Majelis Taklim Jati Agung Lampung Selatan. Melalui penerapan ketiga metode dakwah itu dapat memberi pemahaman tentang keagamaan kepada para jamaah termasuk pengetahuan mengenai mewujudkan keluarga sakinah.

Berikut dapat disimak beberapa metode dakwah yang telah digunakan oleh pengurus pengajian dalam membina masyarakat untuk mewujudkan keluarga sakinah, yaitu:

a. Metode dakwah bil-Hikmah.

Majelis Taklim Jati Agung memang merupakan suatu lembaga keagamaan

\footnotetext{
${ }^{19}$ Depag. RI, Loc. Cit.
} 
memiliki peran yang sangat penting bagi kehidupan masyarakat. Sisi lain yang menarik untuk diteliti adalah semangat dan keinginan yang tinggi bagi pengurus dalam mensyiarkan ajaran agama Islam untuk mewujudkan keluarga sakinah.

Sebagaimana umumnya lembagalembaga pengajian lainnya diberbagai tempat termasuk Majelis Taklim Jati Agung dalam menyampaikan materimateri dakwah dengan menggunakan metode bil-hikmah. Mengembangkan dakwah kepada manusia merupakan kewajiban bagi setiap muslim agar mentaati agama Islam. Mengajak manusia melakukan ritual keagamaan harus mendasarkan dan menjunjung tinggi harkat dan derajat manusia serta memperhatikan latar belakang kondisi masyarakat. Kesadaran itu memberikan pemahaman bahwa penyebaran Islam mendasarkan dan memperhatikan pada kebijakan tertentu yang menyesuaikan kekuatan pengetahuan masyarakat. ${ }^{20}$

Kata hikmah sering dimaknai dengan bijaksana, makna itu telah direalisasikan oleh para da'i dalam menyampaikan pesan-pesannya. Memperhatikan makna itu sang da'i dalam berbagai kesempatan menyebarkan ajaran dakwah dengan memperhatikan kondisi masyarakat, yaitu menitik beratkan pada kemampuan mereka, benar, dan tegas yang didasarkan al-Qur'an dan alSunnah. Banyak pesan-pesan dakwah yang disampaikan dengan metode atau cara bil hikmah yang dapat disesuaikan dengan keberadaan mad'u sehingga akan melahirkan pemahaman yang menyeluruh akhirnya memberikan pengaruh positif dalam kehidupannya.

${ }^{20}$ Hasil Wawancara, Ibu Khalijah, Wakil Ketua Majelis Taklim Jati Agung, Kecamatan Jati Agung Lampung Selatan, tanggal 20 Agustus 2018.
Pesan dakwah dengan bil hikmah telah memberikan kontribusi baik pada perubahan pola sikap, pola fikir, dan pola hidup dari pola hidup yang lama menuju pada pola hidup yang baru, yaitu dapat mempraktekan prinsipprinsip keluarga sakinah.

b. Metode Dakwah Mau’idzah Hasnah.

Metode mau'idzah hasanah merupakan metode dakwah dengan ucapan yang berisi mengenai nasihatnasihat yang baik. Kata mau'idzah hasanah berarti nasehat, bimbingan, pendidikan, dan peringatan yang baik. Hal ini sangat bermanfaat bagi para jamaah pengajian yang mendengarkannya dengan dalil-dalil yang memuaskan dan pada gilirannya jamaah dapat membenarkan segala ucapan yang disampaikan oleh para da'i. Metode mau'idhah hasan ini dalam kegiatan pengajian sangat sering didengar oleh para mad'u. Lebih dari itu dalam acara-acara peringatan tentang mewujudkan keluarga sakinah dalam kehidupan bermasyarakat, istilah mau'idhah hasanah merupakan acara inti. Pada acara inti inilah biasanya dianggap menjadi salah satu target keberhasilan suatu acara pengajian. Isi pesannya atau materi yang di sampaikan bersifat ringan dan informatif, tidak mengundang perdebatan, dan sifat dakwahnya lebih banyak searah dari dai ke audiens.

Penyampaian materi dakwah mengenai prinsip-prinsip keluarga sakinah telah diupayakan mengena dengan kebutuhan mad'u yang bersifat dinamis, harus kontekstual dengan mad'u, dan tidak lebih para da'i harus menguasai materi dan metodologi dakwah maupun kondisi para jamaahnya. Melalui metode ini banyak petuah-petuah da'i, khususnya petuah tentang mewujudkan keluarga sakinah mawaddah wa rahmah, pata jamaah 
telah dipraktekkan dalam kehidupan sehari-hari. $^{21}$

c. Metode Dakwah Mujadalah.

Metode dakwah ini dipergunakan oleh para da'i dalam kegiatan pengajian dengan cara melakukan diskusi dengan mempergunakan akal atau rasio yang dilandasi dengan argumentasi yang berbeda. Menggunakan metode mujadalah diartikan dengan berdiskusi, bertukar pikiran dan memperundingkan, atau perundingan yang ditempuh melalui perdebatan dan pertandingan, untuk mempertahankan pendapatnya.

Metode mujadalah yaitu mmetode dakwah dengan cara yang lebih baik, sejalan dengan pendekatan dakwah yang ditetapkan oleh nash, karena cara ini merupakan pendekatan metode akal yang paling konkrit dan diekspresikan dalam bentuk diskusi, perbandingan, percakapan yang menunjukan kepada makna dan tempatnya. Dalam hal ini menurut Bapak Asep mengemukakan bahwa mujadalah al-lati hiya ahsan ialah: ungkapan dari suatu perdebatan antara dua sudut pandangan yang bertentangan untuk menyampaikan kepada kebenaran yang kebenaran tersebut bertujuan membawa kepada jalan Allah Swt. ${ }^{22}$ Hal ini sesuai dengan situasi dan kondisi dimana masyarakatnya ada beberapa hal yang sering dipersoalkan, seperti: akidah (kemahaesaan Allah), meliputi tentang keesaan Allah SWT., penetapan kerasulan, hari kebangkitan dan

${ }^{21}$ Hasil Wawancara, Bpk. KH. Abdul Adib, MPdI, Penceramah pada Pengajian Majelis Taklim Jati Agung, Kecamatan Jati Agung Lampung Selatan, tanggal 25 September 2018.

${ }^{22}$ Hasil Wawancara, Bapak Asep, Pembina Jamaah pada Pengajian Majelis Taklim Jati Agung, Kecamatan Jati Agung Lampung Selatan, tanggal 16 September 2018. pembalasan, hari akhirat dengan segala keadaannya, neraka dengan segala siksaan azabnya, surga dengan segala nikmatnya dan lainnya. Selain itu juga persoalan budi pekerti yang mulia sebagai dasar pembinaan masyarakat, kebiasaan-kebiasaan yang jelek dari orang orang musyrik, memakan harta anak yatim secara zalim, membunuh anak dan lain sebagainya. ${ }^{23}$

Sejalan dengan tingkat perkembangan dan kemajuan manusia, bentuk mujadalah yang diterapkan mengarah pada diskusi dengan baik untuk menemukan kebenaran, melalui tukar fikiran, atau dalam bahasa komunikasi disebut dengan komunikasi dua arah yaitu terjadi dua komunikasi antara penceramah dengan jamaah. Menurut kenyataan bantahan yang membawa bertukar fikiran dengan baik, ilmiah, rasional, dan objektif menuju kepada petunjuk dan kebenaran.

Melakukan dakwah dengan debat terbuka, sehingga sanggahan atas tanggapan para jamaah dapat diterimanya dengan senang baik, tanpa menimbulkan kesan yang buruk atas pelaksanaan pengajian. Bila terdapat tanggapan balik, maka jawabannya harus dengan argumentasi yang logis dan jelas, sehingga antara kedua belah pihak yang sedang bermujadalah sampai pada suatu kebenaran, tanpa menimbulkan kebencian dan permusuhan. $^{24}$

d. Metode dakwah bil-Lisan atau ceramah.

${ }^{23}$ Hasil Wawancara, Bpk. K. Asep Cholis Nurjamil, M.Kom.I., Penceramah pada Pengajian Majelis Taklim Jati Agung, Kecamatan Jati Agung Lampung Selatan, tanggal 12 September 2018.

${ }^{24} \mathrm{Ustadz}$ Drs. Subariyo, Hasil Wawancara, tanggal 5 Juni 2018, Pimpinan Pengajian Dzikir Karang Anyar, Jati Agung, Lampung Selatan. 
Metode dakwah bil-Lisan adalah salah satu yang dilakukan oleh da'i dan jamaah menyampaikan pesan dakwah mengenai keluarga sakinah dengan menggunakan berbagai refensi. Proses penyampaian materi dakwah mengenai keluarga sakinah diberikan dalam berbagai kesempatan kegiatan pengajian. Dakwah melalui metode ceramah merupakan kegiatan penyebaran ajaran Islam yang disebut dengan istilah Islamisasi via ucapan.

Seorang da'i dengan ucapannya berkewajiban menjelaskan pokokpokok dan intisari ajaran Islam (seperti prinsip-prinsip keluarga sakinah) kepada umatnya melaui ceramah dan khutbah yang berisi nasehat dan fatwa. Metode ini pula dimanfaatkan oleh da'i selain untuk mengajarkan kepada para jamaahnya, juga seringkali mengajarkan atau menghafal lafal-lafal al-Qur'an.

Realisasinya metode ceramah ini, sang da'i menyampaikan materi dakwah mengenai keluarga sakinah kepada jamaahnya dengan lisan. Menggunakan metode lisan ini didasarkan pada kalimat-kalimat yang tepat dan bijak serta pendekatan tertentu, sehingga para jamaah mampu melaksanakan konsep keluarga sakinah dengan baik dan benar. Seperti yang dilakukan oleh seorang penceramah memberikan pemahaman tentang tanggung jawab setiap invidu dalam keluarga.

Diterangkan melalui lisannya mengenai tanggung jawab kepala keluarga, tanggung jawab seorang suami, seorang istri, dan anak serta orang-orang yang ada dalam naungan keluarga. Juga dijelaskan dalam ceramahnya tentang sayarat-syarat, rukun, dan prinsip-prinsip untuk mewujudkan keluarga sakinah. ${ }^{25}$

${ }^{25}$ Hasil Wawancara, Ibu Astuti, Jamaah pada Pengajian Majelis Taklim Jati Agung,
Untuk perkembangan lebih lanjut para pengurus pengajian melakukan aktivitas dakwahnya dengan menggunakan metode dakwah bil lisan ini dalam berbagai kegiatan. Metode ceramah merupakan metode dakwah untuk penyampaian informasi keluarga sakinah melalui tutur kata lisan yang baik. Metode ceramah bersifat satu arah yang diberikan kepada para jamaah dengan tujuan untuk menyampaikan materi yang bersifat abstrak. Lebih lanjut kemudian untuk memberikan informasi yang akan disampaikan, sebagai dasar untuk menambah pengetahuan dan pengamalan keagamaan lebih lanjut.

Selain iu menggunakan metode ceramah dalam menyampaikan materi dakwah agar jama'ah menerima secara jelas dan mampu menjalankan prinsipprinsip keluarga sakinah yang disampaikan oleh para da'i dalam kehidupan sehari-hari. ${ }^{26}$

Menurut salah satu da'i bahwa metode dakwah bil lisan atau ceramah merupakan metode yang paling sering digunakan dalam menyampaikan pesan-pesan dakwah. Harus diingat bahwa penggunaan metode ini harus dikemas sedemikian rupa agar lebih menarik perhatian mad'u dan sesuai dengan kondisi mereka. Ini bertujuan untuk dapat menggugah atau menumbuhkan semangat dan gairah dalam memahami ajaran Islam dan dapat dipraktekkan dalam kehidupan sehari-hari. ${ }^{27}$

Kecamatan Jati Agung Lampung Selatan, tanggal 16 September 2018.

${ }^{26}$ Hasil Wawancara, Ibu Yunarni, Jamaah pada Pengajian Majelis Taklim Jati Agung, Kecamatan Jati Agung Lampung Selatan, tanggal 16 September 2018.

${ }^{27}$ Ustadz Drs. Subariyo, Hasil Wawancara, tanggal 5 Juni 2018, Pimpinan Pengajian Dzikir Karang Anyar, Jati Agung, Lampung Selatan. 
Selain itupula metode ceramah dalam berdakwah memiliki efektivitas tersendiri apabila:

1) Berkaiatan dengan acara-acara ritual seperti khutbah jumat, khutbah hari raya, dikatakan efektif karena hal ini merupakan dari ibadah.

2) Kajian atau materi yang disampaikan berupa tuntunan praktis dan disampaikan kepada jamaah yang terbatas baik jumlah maupun luasnya ruangan.

3) Disampaikan dengan sistem dialog dan bukan monologis, sehingga audien dapat memahami materi dakwah secara tuntas, setidaknya metode ceramah masih dikatakan efektif apabila disertai dengan tanya jawab. $^{28}$

e. Metode dakwah tanya jawab.

Metode tanya jawab akan terjadi hubungan atau interaksi antara sesama yang disebut dengan hubungan dua arah. Melalui tanya jawab merupakan gambaran dari bentuk respon jama'ah terhadap materi yang disampaikan dan akhirnya diharapkan para jama'ah dapat merealisasikan dalam kehidupannya.

Setiap penggunaan metode ini tidak terlepas dari kerja sama antara sang da'i dengan jama'ah, menjadi kebiasan ada materi yang belum dimengerti menjadi lebih mudah dipahami. Pertanyaan yang pertama adalah untuk menggali informasi yang pernah didapatkannya, kedua pertanyaan pemahaman yang berfungsi untuk mengetahui pemahaman jamaah terhadap materi yang pernah disampaikan minggu lalu, dan sang da'i memberikan kesempatan untuk bertanya tentang hal yang belum paham. Contoh: materi mengenai kreteria atau sifat-sifat masyarakat yang

${ }^{28}$ Hasil Wawancara, Ibu Rusdiwanti, Sekretaris Majelis Taklim Jati Agung, Kecamatan Jati Agung Lampung Selatan, tanggal 16 September 2018. sudah menerapkan prinsip-prinsip keluarga sakinah, setelah didiskusikan jamaah mulai faham dan melaksanakannya dalam kehidupan sehari-hari. ${ }^{29}$

Metode tanya jawab adalah suatu metode yang dilakukan dengan cara mengajukan pertanyaan kepada para jama'ah untuk memahami materi dalam rangka pencapaian dakwah yang sudah ditentukan. Tanya jawab merupakan suatu cara proses dakwah dilangsungkan, seorang da'i mengajukan beberapa pertanyaan kepada mad'u mengenai pesan yang telah disampaikan. Pengguanaan metode ini akan memberikan gambaran kepada sang da'i mengenai tingkat pemahaman jama'ah, kemudian memberikan rangsangan pada jama'ah untuk merumuskan ide-ide yang tergali dengan menggunakan kalimat sendiri.

Penerapan metode ini sering digunakan pada awal kajian untuk mereview materi pada pekan sebelumnya dan juga diterapkan pada akhir kajian sebelum ditutup dengan tujuan mengetahui respon dari jama'ah.

f. Metode dakwah bil hal.

Metode dakwah bi al-hal adalah suatu metode dakwah yang tidak hanya ajakan berupa ucapan namun ajakan yang berdimensi perbuatan nyata atau perbuatan yang mengarah pada sesuatu yang riil. Metode ini benar-benar mengedepankan adanya bantuan nyata dari seorang da'i atas sesuatu yang sangat dibutuhkan oleh jamaahnya.

Para jamaah dapat menerima ajakan dakwah sudah barang tentu mengikuti jejak dan hal ikhwal sang da'i, da'i tidak sekedar dibutuhkan uraian teoritis

${ }^{29}$ Hasil Wawancara, Ibu Istiqomah, Jamaah pada Pengajian Majelis Taklim Jati Agung, Kecamatan Jati Agung Lampung Selatan, tanggal 16 September 2018. 
namun ditunggu adanya bantuan nyata untuk meringankan beban pendengarnya. Dakwah yang baik kreterianya adalah isi pesan yang disampaikan isi pesan padat singkat, jelas, isi pesan sesuai dengan rata-rata akal pendengarnya, dan yang lebih penting isi pesan memberi solusi dan bantuan nyata atas permasalahan yang sedang dihadapi oleh mad'u.

Jenis metode dakwah semacam ini memiliki pengaruh nyata terhadap perilaku penerima dakwah ada sugesti untuk mencontohnya. Salah satu da'i pada pengajian Majelis Ta'lim Jati Agung mencontohkan bahwa Rasulullah SAW hijrah dari Mekkah menuju ke Madinah telah berhasil membangun dan membina masyarakat dengan baik. Menurut kenyataan Rasulullah SAW berhasil mempertemukan dan mempersatukan kaum Anshor dan kaum Muhajirin dalam ikatan keluarga yang tentram berdasarkan prinsip-prinsip keluarga sakinah. Demikian juga atas himbauan mubaligh ada beberapa jamaah yang dipertemukan dan dipersatukan atas kasus tertentu, akhirnya mereka tidak bertegoran antara satu dengan lainnya. Atas himbauan tersebut jamaah yang memiliki kasus tersebut rukun kembali dan bersikap bertingkah laku sebagaimana biasanya. Atas usaha itu saat ini masyarakat atau jamaah pengaiian relatif tidak ada lagi yang berseteru tapi hidup saling menghormat, menghargai, dan saling membantu antara satu dengan lainnya.

Dalam kondisi seperti ini mereka hidup rukun dan damai dan di dalam keluarga mereka masing-masing telah terimplementasi konsep dan prinsip- prinsip keluarga sakinah mawaddah wa rahmah. ${ }^{30}$

g. Metode Keteladanan

Metode keteladanan merupakan cara berdakwah dengan mengutamakan pada contoh atau uswatun khasanah. Keteladanan dibutuhkan adanya contoh riil dari pribadi da'i atau para tokoh juga para umara ulama yang sholih seperti kesopanan, kejujuran, keterbukaan, tanggung jawab, disiplin, keperdulian, keadilan, dan lainnya. Untuk melaksanakan metode ini dalam melaksanakan kegiatan dakwah para pengasuh juga menggunakan metode dakwah bil hal, yakni adanya keteladanan dalam melaksanakan sholat jama'ah, maka beliau juga melaksanakan sholat jama'ah. Kemudian ketika beliau menganjurkan untuk bersedekah, maka beliau juga bersedekah sesuai dengan kemampuannya. Juga memberikan contoh pada masyarakat untuk mewujudkan keluarga sakinah dengan mempertimbangkan faktor yaitu lingkungan masyarakat untuk dapat hidup menjalankan syariat Islam penuh taat dan keikhlasan. ${ }^{31}$

2. Manfaat Pengajian dalam Meningkatkan Keagamaan Bagi Jamaah.

Manfaat mengikuti pengajian, seorang utstadz mengatakan bahwa pengajian dalam bahasa Arab disebut At-ta'llimu asal kata ta'allama yata'allamu ta'liiman yang artinya belajar, pengertian dari makna pengajian mempunyai nilai ibadah tersendiri, hadir dalam belajar ilmu

${ }^{30}$ Hasil Wawancara, Ibu Yunarni, Jamaah pada Pengajian Majelis Taklim Jati Agung, Kecamatan Jati Agung Lampung Selatan, tanggal 16 September 2018.

${ }^{31}$ Hasil Wawancara, Ibu Yunarni, Jamaah pada Pengajian Majelis Taklim Jati Agung, Kecamatan Jati Agung Lampung Selatan, tanggal 16 September 2018. 
agama bersama seorang yang berilmu merupakan bentuk ibadah yang wajib setiap muslim. Di dalam pengajian terdapat manfaat yang begitu besar positifnya, pengajian memberi manfaat yang dapat merubah seseorang yang biasa berbuat negatif menjadi positif. Masyarakat muslim dapat memanfatkan pengajian untuk merubah diri dari perbuatan yang keji dan mungkar. ${ }^{32}$

Di jaman modern seperti sekarang ini, nilai-nilai agama seakan-akan telah luntur dari sendi-sendi kehidupan karena habisnya waktu mereka bekerja dan bekerja semaksimal mungkin untuk meraih ambisi keduniawian. Beberapa orang menganggap ritual-ritual ibadah yang hanya beberapa saat itu bahkan menambah ilmu agama dengan mendengarkan ceramah (pengajian ) agama Islam justru menghabiskan waktu produktif mereka saat bekerja. Posisi puncak dalam karier, timbal balik berupa materi yang berlimpah, dan status sosial yang tinggi di mata masyarakat seakan telah menjadi candu yang memabukkan. Tidak jarang rohani pun akhirnya kering dari siraman nilainilai Ke-Tuhanan sehingga menjadi manusia-manusia rapuh yang tak kuat didera masalah, putus asa, atau memilih jalan pintas yang merugikan saat sedang terpuruk. Salah satu cara untuk kembali kepada fitrah kita adalah dengan berkumpul bersama orang-orang saleh dan mengembalikan hak nurani kita akan kebutuhannya untuk mendapatkan cahaya Ke-Tuhanan. Mendengarkan nasehat baik dari ayat suci oleh ahlinya adalah salah satu cara untuk kembali merasakan ketenangan

${ }^{32}$ Hasil Wawancara, Bpk. K. Abdul Adib, M.Pd. I., Penceramah pada Pengajian Majelis Taklim Jati Agung, Kecamatan Jati Agung Lampung Selatan, tanggal 12 September 2018. dalam hidup dan mewujudkan keluarga sakinah.

Contoh lain bagi jamaah mengikuti pengajian. Ceramah yang disampaikan penceramah pada waktu itu sangat menarik mengenai manfaat mengikuti pengajian. Penceramah tersebut sangat mengerti kondisi jamaah, hingga membuat para jamaah yang hadir merasa nyaman. Dan mulai saat itu jamaah menjadi rajin mengikuti pengajian. Setelah acara pengajian itu, jamaah tersebut dan teman-temannya menjadi lebih akrab. Jamaah dan teman-teman sekarang sadar bahwa pengajian banyak manfaatnya,misalnya :

a. Mendapatkan pahala.

b. Ilmu yang bermanfaat juga bisa kita dapatkan melalui pengajian.

c. Lebih akrab dengan teman.

d. Menghargai orang yang sedang berbicara/ceramah.

e. Rajin beribadah dan masih banyak yang lainnya. ${ }^{33}$

Terkait dengan pengajian ini ada beberapa aspek yang dapat ditelaah yaitu: 1) Peningkatan aqidah (ke-Tauhidan) 2) Status sosial dipandang dari segi agama islam, 3) Kelassifikasi sosial dipandang dari aspek ekonomi dan 4) aspek pengetahuan sebagai kewajiban menuntut ilmu bagi kaum ibu-ibu. Sekalipun sudah cukup lama waktu yang dijalani, namun mungkin masih tetap dapat dijadikan suatu gambaran ke depan dimana pengajian ini merupakan aktivitas yang menimbulkan interaksi antar sesama anggota dan pengajar atau ustad yang memberikan berbagai materi dalam rangka pembinaan aqidah Islam serta menumbuhkan kesuburan sikap sosial

${ }^{33}$ Hasil Wawancara, Ibu Yunarni, Jamaah pada Pengajian Majelis Taklim Jati Agung, Kecamatan Jati Agung Lampung Selatan, tanggal 16 September 2018. 
serta meningkatkan pengetahuan umum dan keagamaan.

Dengan kata lain seseorang yang mengikuti pengajian dengan intensitas tinggi atau secara intens, dibarengi dengan kesungguhan, minat yang tinggi dan motivasi yang kuat maka akan berdampak pada religiusitasnya dalam arti kepemilikan seseorang terhadap agamanya akan semakin meningkat yang kemudian teraplikasikan dalam bentuk perilaku nyata di masyarakat.

Berdasarkan temuan di lapangan dapat dikatakan kondisi intensitas mengikuti pengajian Majelis Taklim Kecamatan Jati Agung Kabupaten Lampung Selatan dalam kategori intens dengan pengertian keseringan mengikuti pengajian, kesungguhan, minat, kesenangan, motivasi, perhatian, mencatat dan bertanya ketika ada kesulitan saat mengikuti pengajian yang menjadi indikator kondisi intensitas sangat tinggi. Sementara berdasarkan hasil wawancara dengan informan dalam penelitian ini menujukkan bahwa intensitas pengajian yang diikuti oleh para jamaah karena diadakannya pengajian Ahad pagi yang dilaksanakan di Aula Kecamatan/Balai Desa dengan intensitas yang beragam, seperti jumlah kehadiran setiap minggu hingga dapat mengkuti dua kali dalam sebulan. Selain itu, motif mengikuti pengajian lebih didasari oleh motivasi menuntut ilmu dan wawasan agama Islam, menambah, menjalin silaturrahim dan pengurus $\mathrm{Al}$ Hidayah Kecamatan Jati Agung Kabupaten Lampung Selatan, sehingga dapat meningkatkan keimanan, turut membina tentang hukum/ aqidah agama yang semestinya berdasarkan AlQur'an dan Hadis dan hidup yang bermanfaat bagi orang lain serta mendapatkan ridho Allah.

Hal lain yang disampaikan oleh para informan diungkapkan bahwa kondisi intensitas mengikuti pengajian Majelis Taklim Kecamatan Jati Agung Kabupaten Lampung Selatan termasuk dalam katagori intens dalam pengertian seringan mengikuti pengajian, kesungguhan, minat, kesenangan, motivasi, perhatian, mencatat dan bertanya ketika ada kesulitan saat mengikuti pengajian.

Peningkatan religiusitas setelah mengikuti pengajian juga meningkat yang meliputi 5 (lima) indikator yakni indikator peningkatan keimanan (Religious of beliefs (ideological), rajin beribadah, (Religious of practice ritualistic), bertambah pengalaman keagamaan (Religious of feeling experiential), minat mempelajari agama (Religious of knowledge intellectual), konsekuen menjalankan agama, (Religious of effect consequential).

Salah satunya terdapat pemahaman keberagamaan seperti, peningkatan keimanan, rajin beribadah, bertambah pengalaman keagamaan, minat mempelajari agama, konsekuen menjalankan agama, peningkatan pengamalan keagamaan dan perasaan tenang setelah mengikuti pengajian. Dari berbagai penuturan informan dapat dikatakan ada peningkatan keberagamaan ibu-ibu dalam mengikuti Pengajian Majelis Taklim Kecamatan Jati Agung Kabupaten Lampung Selatan .

Para jamaah sudah menyadari bahwa dalam beribadah kepada Allah SWT tidak boleh dicampuri dengan perkara lain, tapi harus dimurnikan ikhlas karena Allah SWT dan tidak menyembah kepada yang lainnya, karena itu berbuatan syirik. Dalam alQur'an surat az-Zumar (39), ayat 2-3 disebut bahwa menyembah Allah SWT dengan memurnikan ketaatan kepadaNya berbunyi: 


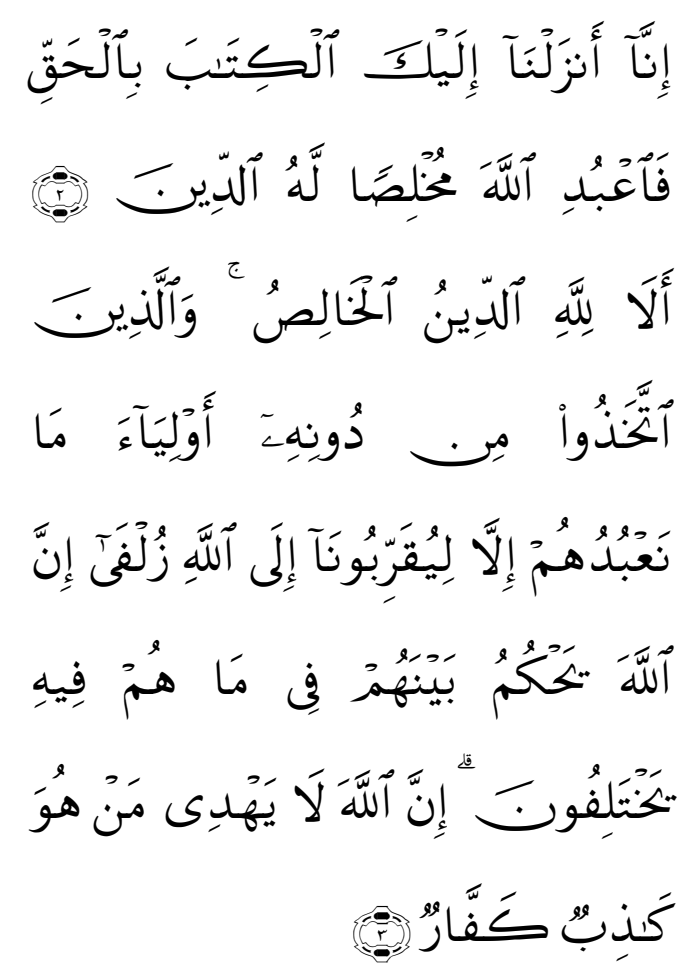

Sesunguhnya Kami menurunkan kepadamu kitab (Al Quran) dengan (membawa) kebenaran. Maka sembahlah Allah dengan memurnikan ketaatan kepada-Nya. Ingatlah, hanya kepunyaan Allah-lah agama yang bersih (dari syirik). dan orang-orang yang mengambil pelindung selain Allah (berkata): "Kami tidak menyembah mereka melainkan supaya mereka mendekatkan Kami kepada Allah dengan sedekat- dekatnya". Sesungguhnya Allah akan memutuskan di antara mereka tentang apa yang mereka berselisih padanya. Sesungguhnya Allah tidak menunjuki orang-orang yang pendusta dan sangat ingkar. (Q.S. az-Zumar (39), 2-3). ${ }^{34}$

Berkenaan keimanan yang kuat membaja bahwa para jamaah pasrah terhadap kekuasaan Allah SWT. Hanya Allahlah satu-satunya Tuhan yang

${ }^{34}$ Hasil Wawancara, Ibu Siti Aminah, Jamaah pada Pengajian Majelis Taklim Jati Agung, Kecamatan Jati Agung Lampung Selatan, tanggal 20 Agustus 2018. memiliki, merencanakan, menciptakan, mengatur, memelihara, memberi rezeki, memberikan manfaat, menolak mudharat serta menjaga seluruh alam semesta ini. Seluruh jamaah tidak ada seorang pun yang mengingkarinya. Orang-orang yang mengingkari-Nya adalah kafir, sebab mereka tampak dalam kehidupannya mengingkari-Nya. $\mathrm{Hal}$ itu merupakan kesombongan manusia, jauh-jauh sejak lahir dalam lubuk hati mereka dibekali ketauhidan berupa fitrah Islam, berarti mereka membohongi fitrahnya.

Unsur ketauhidan/keyakinan seperti di atas yang dialami oleh jamaah pengajian menunjuk pada tingkat keyakinan yang sangat baik dan kuat serta benar. Keyakinan semacam itu baik yang berhubungan dengan ajaranajaran yang bersifat fundamental/ dogmatic maupun yang lainnya harus diperlihara dengan baik. Adanya keyakinan terpelihara dengan baik dan benar, insya Allah para jamaah dalam menaungi perjalanan hidup diwarnai dengan keyakinan yang mengarahkan kehidupannya ke arah ridho Allah SWT. Namun demikian apabila seseorang dalam perjalanannya diwarnai dengan pembangkangan pada ajaran ketauhidan, maka orang tersebut bisa rusak binasa dalam kehidupannya. Untuk menjaga kemurnian ketauhidan seseorang seyogyanya harus diberi atau mendapatkan pencerahan secara terus menerus tentang ketauhidan yang bersumber dari al-Qur'an dan alHadits. Melalui pencerahan yang benar dapat dipastikan keimanan seseorang tidak tergoyahkan dengan berbagai godaan baik dari dirinya maupun dari luar dirinya. Dalam kondisi seperti ini keimanan seseorang akan terjaga dengan baik sehingga dalam tingkah lakunya dituntun dengan kebaikan 
berkat iman yang yang baik dan benar yang dimilikinya.

\section{Kesimpulan}

Kedudukan metode dalam kegiatan dakwah memiliki peran yang sangat penting, karena metode merupakan suatu jalan yang ditempuh oleh mubaligh untuk meraih hasil yang diinginkannya. Materi dakwah yang disampaikan kepada mad'u dapat dimengerti dengan mudah dikarenakan metode dakwah yang dipilihnya tepat dan sesuai dengan kondisi para mad'unya. Kenyataan di lapangan para da'i dalam dakwahnya telah memiliki metode atau mempratekkan metode tertentu dalam menyampaikan pesanpesan keagamaan kepada para pendengarnya. Melalui metode yang diterapkan para pendengar menerimanya dengan baik dan suka cita yang pada akhirnya para pendengan atau jama'ah pengajian merubah perilakunya sesuai dengan tuntunan ajaran Islam.

Sesuai dengan kenyataan yang ada bahwa metode-metode yang dipraktekan oleh da'i memiliki pengaruh yang sangat besar terhadap penerimaan materi dakwah mengenai keluarga sakinah. Dengan metode, kalimat-kalimat yang bijak dan pendekatan tertentu, sehingga para jamaah mampu melaksanakan konsep keluarga sakinah dengan baik dan benar. Seperti yang dilakukan oleh seorang penceramah memberikan pemahaman tentang tanggung jawab setiap invidu dalam keluarga.

Diterangkan melalui lisannya mengenai tanggung jawab kepala keluarga, tanggung jawab seorang suami, seorang istri, dan anak serta orang-orang yang ada dalam naungan keluarga. Juga dijelaskan dalam ceramahnya tentang sayarat-syarat, rukun, dan prinsip-prinsip untuk mewujudkan keluarga sakinah.

Kondisi di atas merupakan kenyataan yang harus dipraktekan oleh kaum muslimin dalam kehidupan sehari-hari. Masyarakat muslim jamaah pengajian Majelis Taklim Jati Agung Lampung Selatan telah berhasil menciptakan tatanan kehidupan yang berdasarkan pada prinsip-prinsip keluarga sakinah. Keberhasilan dalam mewujudkan kehidupan seperti itu tidak terlepas dari peranan Pengurus Pengajian Majelis Taklim Kecamatan Jati Agung Lampung Selatan. Keberhasilan itu membuktikan bahwa para da'i telah mempraktekan beberapa metode atau cara-cara dalam kegiatan pengajian pada Majelis Taklim untuk mewujudkan keluarga sakinah dalam kehidupan bermasyarakat di Kecamatan Jati Agung Lampung Selatan.

Hubungannya dengan penelitian yang dilakukan ini bahwa, sesuai dengan alur penelitian yang dilakukan diperoleh data sesuai dengan permasalahan penelitian. Langkah berikutnya data tersebut dilakukan analisis, kemudian diambil beberapa kesimpulan yaitu:

1. Pengurus Pengajian Majelis Taklim Kecamatan Jati Agung memalui berbagai kegiatannya telah membina tatanan kehidupan masyarakat yang harmonis. Dalam mewujudkan kondisi itu pengurus telah menghadirkan beberapa penceramah untuk membina masyarakat dengan pola melaksanakan prinsip-prinsip keluarga sakinah. Adapun metode yang digunakan oleh para da'i dalam mewujudkan kehidupan masyarakat yang mempraktekkan prinsipprinsip keluarga sakinah antara lain: 
a). Metode bil-hikmah. Sebagaimana umumnya lembaga-lembaga pengajian lainnya diberbagai tempat termasuk Majelis Taklim Jati Agung dalam menyampaikan materi-materi dakwah dengan menggunakan metode bilhikmah. Mengajak manusia melakukan ritual keagamaan harus mendasarkan dan menjunjung tinggi harkat dan derajat manusia serta memperhatikan latar belakang kondisi masyarakat. Kesadaran itu memberikan pemahaman bahwa penyebaran Islam mendasarkan dan memperhatikan pada kebijakan tertentu yang menyesuaikan kekuatan pengetahuan masyarakat.

b). Metode mau'idzah hasanah merupakan metode dakwah dengan ucapan yang berisi mengenai nasihat-nasihat yang baik. Kata mau'idzah hasanah berarti nasehat, bimbingan, pendidikan, dan peringatan yang baik. Hal ini sangat bermanfaat bagi para jamaah pengajian yang mendengarkannya dengan dalildalil yang memuaskan dan pada gilirannya jamaah dapat membenarkan segala ucapan yang disampaikan oleh para da'i.

c). Metode Dakwah Mujadalah. Metode dakwah ini dipergunakan oleh para da'i dalam kegiatan pengajian dengan cara melakukan diskusi dengan mempergunakan akal atau rasio yang dilandasi dengan argumentasi yang berbeda. Menggunakan metode mujadalah diartikan dengan berdiskusi, bertukar pikiran dan memperundingkan, atau perundingan yang ditempuh melalui perdebatan dan pertandingan, untuk mempertahankan pendapatnya.

d). Metode dakwah bil-Lisan adalah salah satu yang dilakukan oleh da'i dan jamaah menyampaikan pesan dakwah mengenai keluarga sakinah dengan menggunakan berbagai refensi. Proses penyampaian materi dakwah mengenai keluarga sakinah diberikan dalam berbagai kesempatan kegiatan pengajian. Dakwah melalui metode ceramah merupakan kegiatan penyebaran ajaran Islam yang disebut dengan istilah Islamisasi via ucapan.

e). Metode tanya jawab akan terjadi hubungan atau interaksi antara sesama yang disebut dengan hubungan dua arah. Melalui tanya jawab merupakan gambaran dari bentuk respon jama'ah terhadap materi yang disampaikan dan akhirnya diharapkan para jama'ah dapat merealisasikan dalam kehidupannya.

f). Metode dakwah bi al-hal adalah suatu metode dakwah yang tidak hanya ajakan berupa ucapan namun ajakan yang berdimensi perbuatan nyata atau perbuatan yang mengarah pada sesuatu yang riil. Metode ini benar-benar mengedepankan adanya bantuan nyata dari seorang da'i atas sesuatu yang sangat dibutuhkan oleh jamaahnya. Jenis metode dakwah semacam ini memiliki pengaruh nyata terhadap perilaku penerima dakwah ada sugesti untuk mencontohnya.

g). Metode keteladanan merupakan cara berdakwah dengan mengutamakan pada contoh atau uswatun khasanah. Keteladanan dibutuhkan adanya contoh riil dari pribadi da'i atau para tokoh 
juga para umara ulama yang sholih seperti kesopanan, kejujuran, keterbukaan, tanggung jawab, disiplin, keperdulian, keadilan, dan lainnya.

2. Manfaat Pengajian dalam Meningkatkan

Keagamaan Bagi Jamaah.

Dengan diadakannya pengajian yang dilakukan secara rutin, pada umumnya mempunyai beberapa manfaat atau tujuan sebagai berikut:

a. Meningkatkan silaturahmi; dalam suatu majelis agama, kita akan bertemu dengan saudara-saudara kita sesama umat muslim sehingga hubungan dengan saudara-saudara kita akan semakin erat. Dikatakan orang yang menyambung persaudaraan akan dipanjangkan umurnya dan dilipatgandakan rezekinya.

b. Dapat meningkatkan iman dan takwa; iman dan takwa dalam hati akan meningkat jika kita rajin membersihkan hati dengan cara, membersihkan muka dengan air mata yang teringat dosa, membersihkan lidah dengan dzikir kepada Allah, membersihkan dosa dengan bertobat, dan membersihkan hati dengan bertakwa.

c. Mengingatkan diri sendiri; melalui ceramah agama Islam, kita akan selalu diingatkan untuk melaksanakan ibadah demi kebahagiaan hidup di dunia dan akhirat. Jika akhirat yang menjadi prioritas kita dalam hidup maka secara otomatis dunia akan menjadi milik kita.

d. Menambah ilmu; dalam ceramah agama kita akan mendapatkan tambahan ilmu agama yang akan lebih menyempurnakan iman dan ibadah kita sehari-hari. Sangat penting untuk belajar agama langsung dari ahlinya bila kita sejak kecil menempuh pendidikan umum, karena tentang ilmu agama tidak dapat dipelajari sendiri.

Menyimak perkembangan jaman yang ada bahwa masyarakat Kecamatan Jati Agung dalam kehidupannya sangat kondusif, hal ini tidak dipungkiri berkat salah satunya adanya sumbangsing dari banyaknya aktivitas pengajian yang begitu semarak diikuti oleh masyarakat.

Pembahasan mengenai metode dakwah untuk membinaan pada masyarakat dalam mewujudkan hidup keluarga sakinah, hendaknya kepada tokoh agama dan tokoh masyarakat menyadari betul betapa pentingnya dijadikan pedoman dalam kegiatan pengajian. Upaya mewujudkan kehidupan keluarga sakinah akan memberi respon perubahan yang baik dalam menghadapi kehidupan yang berkemajuan dan moderen. Untuk itu kepada seluruh unsur masyarakat dan pemerintah hendaklah mendukung kegiatan pengajian dan membantu mewujudkan kehidupan yang berlandaskan prinsip-prinsip keluarga sakinah.

\section{Daftar Pustaka}

Abdullah, Dzikron, 1988, Metodologi Dakwah, Fakultas Dakwah IAIN Walisongo, Semarang.

Abdul Kadir Masyi, 1981, Metode Dikusi Dalam Dakwah, Penerbit AlIkhlas, Surabaya.

Abdurahman An Nahlawi, 1996, Pendidikan Islam di Rumah dan Masyarakat, terj. Sihabuddin, Bulan Bintang, Jakarta.

Abdurrahman Khalik, 1996, Metode dan Strategi Dakwah, Pustaka AlKautsar, Jakarta. 
Abu Ahmadi dan Widodo Supriyono, 2004, Psikologi Belajar, Rineka Cipta, Jakarta.

Ahmad Muadz Haqiqi, 2003, Berbias dengan 40 Akblakul Karimah, Cahaya Tauhid Press, Malang.

Ali, Maulavi Muhammad, 1950, Mubammad The Prophet, Iradahi alAdabiyati, Lahore.

Al-Attas, Muhammad Naquib, 1976, Islam; The Concep of Religion and The Fundation of Ethics and Morality, Yayasan Anda Akademika, Kualalumpur.

Anwar Arifin, 1984, Strategi Komunikasi, Suatu Pengantar Ringkas, Armico, Bandung.

Asmuni Syukir, 1983, Dasar-Dasar Strategi Dakwah, Penerbit AlIkhlas, Surabaya.

Barmawi Umarie, 1991, Materi-Materi Akblak, Penerbit Ramadhani, Solo.

Bellah, Robert N., 1976, Islamic Tradition and Problem of Modernization, Harper Row, New York.

Benyamin Spock, 1981, Masalab Orang Tua Menghadapi Remaja, Penerbit Bharata Karya Aksara, Bandung.

Deddy Mulyana, 2005, Imu Komunikasi Suatu Pengantar, Remaja Rosyda Karya, Bandung.

Departemen Agama RI, 2001, AlQur'an dan Terjemabnya, Penerbit Thoha Putra, Semarang.
2004, Membiasakan Tradisi Agama, Departemen Agama RI, Jakarta.

Hasan Basri, 1995, Keluarga Sakinah Tainjauan Psikologis dan Agama, Pustaka Pelajar, Yogyakarta.

Hamzah Ya'cub, 1983, Etika Dalam Islam, Penerbit Diponegoro, Bandung.

Hasby Ash-Shiddiqy, 200, Kuliah Ibadah, Penerbit Pustaka Rizki Putra, Semarang.

Henry N. Siahaan, 1989, Peranan Ibu Bapak Dalam Mendidik Anak, Penerbit Angkasa, Bandung.

Hussein Bahreisy,1981, Ajaran-Ajaran Akblak Menurut Imam Al-Ghazali, Penerbit Al-Dalas, Surabaya.

Ibnu Hamad, 2012, Pendidikan Karakter Untuk. Menyiapkan Generasi 100 Tabun Kemerdekaan Indonesia 2045, Modul Kemendikbud., Bandar Lampung.

Ibnu Hisyam, Imam Muhammad Abd. Malik, 1955, al-Sirat alNabawiyyah, Musthafa al-Babi alHalabi, Jilid, Kairo.

Ibnu Katsir, al-Imam Abu Fida' Ismail, t.th., al-Sirah al-Nabawiyyah, Isa alBabi al-Halabi, Kairo.

al-Ismail, Tahia, 1966, Kitab Tarikh Nabi Mubammad $S A W$, Dar alFikr, Bairut.

al-Muhasibi, Muhammad Haseim, t.th., Tafsir wa Bayan Ma'a Sabab alNuzul Li al-Suyuthi, Dar alRasyid, Bairut. 
Jamaluddin Kahfi, 1996, Kebahagiaan Menurut Pandangan Islam, Pustaka Al-Kautsar, Surabaya.

Josep A Devito, 1997, Komunikasi Antar Manusia, Terj. Mulyana, Profesional Books, Jakarta.

Kartini Kartono, 2001, Pengantar Metode Research Sosial, Penerbit Alumni, Bandung.

Khalillah Marhiyanto, tt., Menciptakan Kebidupan Sakinah, Bintang Pelajar, Gresik, Jawa Timur.

Khaliq Abdurrahman, 1996, Metode dan Strategi Dakwah Islam,Pustaka AlKautsar, Jakarta.

Little John, 1999, Theories of Human Communication, Belmont, Wordsworth Publishing Company, California.

Lubis Salam, 1999, Keluarga Sakinah, Penerbit: Terbitlah Terang, Surabaya.

M. Ali Hasan, 1978, Tuntunan Ajaran Akblak, Penerbit Bulan Bintang, Bandung.

M. Ali Quthb, 1983, Sang Anak Dalam Naungan Pendidikan Islam, Penerbit Diponegoro, Semarang.

M. Basyiruddin Usman, 2002, Metodologi Pembelajaran Agama Islam, Ciputat Press, Jakarta.

M. Hari Wijaya, tt., Panduan Mendidik dan Membentuk Watak Anak, Luna Subleser, Yogyakarta.

Muhammad Budiyatna, 2011, Teori Komunikasi Antarpribadi, Penerbit Kencana, Jakarta.
Mustafa Kamal, 1990, Akblak Sunnah, Penerbit Al Maarif, Bandung.

Munsyi, A. Kadir, 1978, Metode Diskusi Dalam Dakwah, Penerbit AlIkhlas Surabaya.

Muria, Siti, 2000, Metodologi dakwah Kontemporer, Mitra Pustaka, Yogyakarta.

Onong Uchjana Effendy, 2006, Teori dan Praktek Ilmu Komunikasi, Rosyda Karya, Bandung.

Pimpinan Pusat Muhammadiyah Aisyiyah, 1989, Tuntunan Menuju Keluarga Sakinah, PP Muhammadiyah, Yogyakarta.

Salihun A Nasir, 1980, Etika dan Problemanya Dewasa Ini, Penerbit $\mathrm{Al}$ Maarif, Bandung.

Singgih D. Gunarsa, 1983, Psikologi Perkembangan Anak dan Remaja, BPK Gunung Mulia, Jakarta.

Suharsimi Arikunto, 2002, Prosedur Penelitian Suatu Pendekatan Praktis, Penerbit Rineka Cipta, Jakarta.

Sugiyono, 2007, Metode Penenltian Pendidikan Pendekatan Kuantitatif, Kualitatif, dan $\mathrm{R} \& \mathrm{D}$, Penerbit Alfabeta, Bandung.

S. Marogono, 2004, Metode Penelitian Pendididkan, Penerbit Rinieka Cipta, Jakarta.

S. Nasution, 1996, Metode research (Penelitian Ilmiah), Penerbit Bumi Aksara, Jakarta. 
Syamsu Yusuf, 2004, Psikologi Perkembangan Anak dan Remaja, Rosyda Karya, Bandung.

Syarkawi, 2004, Pembentukan Kepribadian Anak, Penerbit Bina Aksara, Jakarta.

Thamrin Nasution dan Nurhalijah Nasution, 1985, Perana Orang Tua Dalam Meningkatkan Prestasi Belajar Anak, Kanisius, Yogyakarta.

Veithzal Rivai, 2009, Kepemimpinan Dan Prilaku Organisasi, Raja Grafindo Persada, Jakarta.

--------, 2009, Manajemen Sumber Daya Manusia Untuk Perusahaan Dari Teori dan Praktek, Rajawali Pers, Jakarta.

Zahara Maskanah dan Tayar Yusuf, 1982, Membina Ketentraman Batin Melalui Akblak Etika Agama, Indo Hill, Co, Jakarta.

Zainal Aqib Sujak, 2011, Pendidikan Karakter Membangun Perilaku Positif Anak Bangsa, Yarama Widya, Bandung.

Zakiah Daradjat, dkk., 1976, Imu Jiwa Agama, Penerbit Bulan Bintang, Jakarta.

-------, 1987, Islam Untuk Disiplin Ilmu Pendidikan, Bulan Bintang. 